\title{
FONOLOGI BAHASA ARAB \\ (Tinjauan Deskriptif Fonem Bahasa Arab)
}

Oleh :

Muhammad Afif Amrulloh,M.Pd.I

\begin{abstract}
Bahasa sebagai objek kajian linguistik memiliki peran penting dalam kehidupan manusia. Bahasa dan kehidupan adalah fenomena yang tidak dapat dilepaskan layaknya dua sisi mata uang. Bahasa merupakan sistem lambang bunyi arbitrer yang digunakan oleh manusia untuk saling berkomunikasi antar sesama. Sebagai sebuah sistem, bahasa memiliki sifat sistematis (berkaedah) dan sistemis (bersubsistem). Salah satu subsistemnya yaitu fonologi. Fonologi sebagai salah satu bidang atau tataran kajian dalam ilmu linguistik yang membahas terkait segala yang berhubungan dengan bunyi-bunyi bahasa. Bunyi bahasa ini dikategorikan menjadi dua yaitu fonetik dan fonemik. Fonetik sebagai cabang dari fonologi membahas terkait bunyi bahasa tanpa mempengaruhi makna, sedangkan fonem membahas tentang bunyi bahasa yang berpengaruh terhadap makna. Tulisan ini ingin mengkaji tentang fonologi bahasa Arab, khususnya pada aspek fonemnya. Kajian ini termasuk dalam lingkup pembahasan ilmu $a l-A s w a>t$, yaitu ilmu yang membahas tentang penuturan bunyi bahasa, perpindahan dan penerimaannya. Sebelum mempelajari cara penyusunan struktur suatu bahasa beserta makna dan sebagainya, maka terlebih dahulu harus mengenal bunyi-bunyi bahasa yang ada di dalamnya. Bunyi bahasa adalah yang pertama kali harus dikenal terlebih dahulu bagi para pembelajar bahasa (bahasa Arab). Oleh karena itu, fonologi menjadi penting untuk dipelajari dalam pembelajaran dan penguasaan bahasa (bahasa asing). Dengan demikian, menjadi sangat penting untuk memahami kajian fonologi atau al-Aswa>t, sehingga diperoleh pemahan yang menyeluruh terkait bunyi bahasa Arab yang tentunya setiap bunyi bahasa memiliki arti tersendiri.
\end{abstract}

Kata kunci : Fonologi,Fonem, Aswat. 


\section{A. PENDAhULUAN}

Bahasa sebagai objek kajian linguistik memiliki peran penting dalam kehidupan manusia. Bahasa dan kehidupan merupakan fenomena yang tidak dapat dilepaskan. Keberbutuhan manusia terhadap bahasa menjadi sangat utama dalam pemenuhan kebutuhan dan keberlangsungan kehidupan interaksi antar sesama. Perlu kita ketahui bahwa bahasa yang dimaksud di tulisan ini yaitu sistem bunyi ujar atau yang diucapkan. Bahasa pada hakekatnya memang berupa bunyi yang diucapkan. Bunyi ini berlaku untuk semua bahasa manusia, khususnya yaitu bahasa Arab. Bunyi-bunyi yang diketahui atau dikenal oleh seseorang dan selanjutnya dirangkai sehingga menjadi ujaran yang memiliki makna.

Bahasa merupakan sistem lambang bunyi arbitrer yang digunakan oleh manusia untuk saling berkomunikasi. Sebagai sebuah sistem, bahasa memiliki sifat sistematis (berkaedah) dan sistemis (bersubsistem). Bahasa bersubsistem mencakup fonologi, gramatikal dan leksikal. Pembahasan ketiga aspek tersebut (subsistem) menurut Yayat Sudaryat bertemu dalam kajian bunyi (fonologi) dan makna (semantik). Bunyi dan makna menjadi tempat pertemuan ketiga subsistem tersebut. ${ }^{1}$ Khusus untuk tulisan ini akan menguraikan secara detai terkait kajian bunyi atau fonologi.

Salah satu bidang atau tataran kajian dalam ilmu linguistik yaitu fonologi. Bidang ini akan membahas terkait segala yang membicarakan tentang bunyi-bunyi bahasa. Bunyi bahasa yang harus dikenal terlebih dahulu bagi para pembelajar bahasa (bahasa Arab). Sebelum mempelajari cara penyusunan struktur suatu bahasa beserta makna dan sebagainya, maka terlebih dahulu harus mengenal bunyi-bunyi bahasa yang ada di dalamnya. Antara bunyi dan suara jelas keduanya tidaklah sama, mengingat bunyi bisa dihasilkan dari berbagai gesekan benda maupun alat suara dari manusia. Menurut Kridalaksana yang dimaksud bunyi yaitu kesan pada pusat syaraf sebagai akibat dari getaran gendang telinga yang bereaksi karena perubahanperubahan dalam tekanan udara. ${ }^{2}$ Berdasarkan pengertia tersebut di atas, maka

\footnotetext{
${ }^{1}$ Yayat Sudaryat.Makna dalam Wacana,(Bandung: CV Yrama Widya,2009),hlm.2.

${ }^{2}$ Harimurti Kridalaksana,Kamus Linguistik,(Jakarta: Gramedia,1983),hlm.27.
} 
tampak jelas bahwa yang dimaksud bunyi pada bahasa di sini yaitu bunyi yang dihasilkan oleh alat ucap manusia.

Setiap bunyi yang tidak dihasilkan dari alat ucap manusia bukan lah merupakan bunyi bahasa. Meskipun ada beberapa bunyi yang keluar dari alat ucap manusia yang tidak dapat dipahami maksudnya sehingga tidak termasuk bunyi bahasa. Misanya seperti batuk, bersin dan lain sebagainya bukan merupakan bunyi bahasa karena tidak termasuk sistem bunyi bahasa. Secara lebih jelas, bahwa bunyi bahasa bisa dikatakan dengan bunyi ujaran, yiatu satuan bunyi yang dihasilkan oleh alat ucap manusia yang di dalam fonetik sebagai fond dan di dalam fonemik sebagai fonem. ${ }^{3}$ Hal ini lah yang akan dibahas pada tulisan ini yaitu kajian linguistik berupa fonologi dalam bahasa asing, khususnya bahasa Arab. Pada tulisan ini, dibicarakan tentang fonologi bahasa Arab pada aspek fonemnya.

Sistematika penulisannya adalah pengantar, pengertian fonologi, kerangka teori fonologi, deskripsi bunyi fonem bahasa Arab dan kemudian penutup.

\section{B. PENGERTIAN FONOLOGI}

Istilah penggunaa fonologi berasal dari gabungan dua kata dari bahasa Yunani, yaitu phone dan logos. Phone yang berarti bunyi, dan logos yang berarti tatanan, ilmu. Penjelasan tentang fonologi ini seperti dipaparkan oleh beberapa ahli, yaitu di antaranya menurut Abdul Chaer, fonologi berasal dari fon (bunyi) dan logi (ilmu). Segingga secara terminologi bahwa fonologi yaitu bidang linguistik yang mempelajari, menganalisis dan membicarakan runtutan bunyi-bunyi bahasa. ${ }^{4}$ Berdasarkan pengertian tersebut dapat kita pahami bahwa pembahasan dalam linguistik yang khusus membahas tentang runtutan bunyi-bunyi bahasa yang dikenal dengan nama fonologi.

Dalam bahasa Arab ilmu bunyi atau fonologi ini dikenal dengan nama ilmu alAswa $>t$. ilmu al-Aswa $>t$ yaitu ilmu yang membahas tentang pembentukan, perpindahan dan penerimaan bunyi bahasa. ${ }^{5}$ Mulai dari pembentukan bunyi bahasa hingga menjadi ujaran yang bermakna yang disampaikan kepada lawan tutur melalui

\footnotetext{
${ }^{3}$ Abdul Chaer,Linguistik Umum,(Jakarta:Rineka Cipta,2007),hlm.43.

${ }^{4}$ Ibid,hlm.102.

${ }^{5}$ Muhammad Ali Al-Khouli,Mu’jam Ilmu Al-Aswat,(Riyadh:Universitas Riyadh.Cet I, 1982),hlm.112.
} 
bahasa yang kesemuanya ini menjadi kajian dalam fonologi. Termasuk juga di dalamnya terkait fungsi dan makna yang terkandung dalam suatu bunyi tersebut. Istilah lain dari fonologi yaitu ilmu $a l-A s w a>t$, yaitu ilmu yang membahas tentang penuturan bunyi bahasa, perpindahan dan penerimaannya.

Berdasarkan pemaparan tentang fonologi di atas, maka dapat kita pahami bahwa fonologi merupakan salah satu bidang linguistik yang membahas tentang bunyibunyi bahasa. Bunyi bahasa ini dikategorikan menjadi dua yaitu fonetik dan fonemik. Sebagai cabang dari fonologi, bahwa fonetik membahas terkait bunyi bahasa tanpa mempengaruhi makna, sedangkan fonem membahas tentang bunyi bahasa yang berpengaruh terhadap makna. Untuk lebih detail akan dipaparkan terkait fonologi pada pembahasan berikut ini.

\section{TEORI FONOLOGI}

\section{Pembagian Kajian Fonologi}

Dalam pembahasan fonologi atau ilmu $a l-A s w a>t$, bunyi-bunyi bahasa ini dapat dikategorikan menjadi:

a. Fonetik, salah satu cabang ilmu bunyi yang khusus membicarakan masalahmasalah bunyi tanpa memperhatikan fungsi dan makna bunyi tersebut. Misanya cara memproduksi suatu bunyi, makhraj dan sifatnya.

b. Fonem adalah bagian atau kesatuan terkecil dari sistem bunyi bahasa yang mempunyai fungsi tersendiri sebagai pembeda makna. Untuk mengidentifikasi suatu fonem dapat dilakukan dengan cara membandingkan dua satuan bahasa yang memiliki kemiripan bunyi yang tentunya makna yang terkandung tidak sama. Apabila diganti dengan huruf yang lain maka makna yang terkandung akan menjadi berubah. Misalnya dalam bahasa Arab ditemukaan adanya fonem pada kata خسوف - كسوف. Kedua kata tersebut memiliki kemiripan bunyi dan jumlah bunyinya sama (empat bunyi). Perbedaan huruf terletak pada dua huruf yang tentunya mempengaruhi terhadap makna yang berbeda. Huruf $n$ dan $b$, keduanya adalam merupakan fonem. Jika $n$ dalam kata nasi dan kemudian diganti dengan $b$ maka akan 
menjadi basi, sehingga hal ini akan mempengaruhi terhadap perubahan makna.

c. Alofon, yaitu bagian terkecil dari bahasa yang tidak memiliki fungsi pembeda, jika diganti maka tidak akan berpengaruh terhadap perubahan makna. Misalnya nun izhar dengan nun ikhfa, lam mufakham dengan lam muraqqaq. Sehingga lam mufakham dalam والله jika diganti dengan lam muraqqaq, maka hal ini tidak akan memunculkan perubahan makna. ${ }^{6}$

2. Macam Bunyi

Berdasarkan pertimbangan pada karakteristik bunyi, para linguis membagi bunyi menjadi tiga macam, yaitu:

a. Vokal atau صو ائت، حركات

Vokal merupakan suatu bunyi yang dihasilkan daru getaran pita suara dengan tanpa ada penyempitan dalam saluran suara di atas glottis.(1). Bunyi bahasa ini proses arus udaranya berjalan dengan lancar, tidak dijumpai rintangan atau kesulitan. Vokal dalam bahasa Arab mencakup bunyi fathah, kasrah dan dhammah. Bunyi ini termasuk bunyi yang bersuara yang prosesnya dengan penerobosan terhadap klep pita suara melalui tekanan. Sedangkan pembentukkannya, udara yang datang dari paru-paru tidak mendapat hambatan di kerongkongan dan rongga mulut serta tidak mendapatkan penyempitan di saluran udara yang mengakibatkan adanya geseran.

Sedangkan macam bunyi vokal dalam bahasa Arab menurut para linguis fonetik Arab dibagi menjadi tiga aspek, yaitu berdasarkan panjang pendeknya vokal, tebal tipisnya vokal dan tunggal majemuknya vokal. ${ }^{7}$

1. Aspek Panjang Pendeknya Vokal

Sebagaimana yang disebutkan di dalam buku al-Aswat al-'Arabiyyah karya Kamal Muhamed Bisyr, bahwa pembagian vokal dibagi menjadi 2010),hlm.2.

${ }^{6}$ Ahmad Sayuti Anshari Nasution,Bunyi Bahasa;Ilm Al-Ashwat Al-'Arabiyyah,(Jakarta:Amzah,

${ }^{7}$ Ibid,hlm.87-91 
dua macam, yaitu vokal panjang dan vokal pendek. ${ }^{8}$ Berikut penjelasan masing-masing jenis vokal tersebut.

- Vokal Panjang

Vokal panjang dalam bahasa Arab disebut juga dengan mad. Maksud vokal panjang yaitu bahwa dalam pengucapannya membutuhkan waktu dua kali dari durasi pengucapan vokal pendek. Tanda atau huruf yang digunakan untuk menunjukkan vokal panjang dalam bahasa Arab di antaranya yaitu huruf alif yang didahului oleh fathah

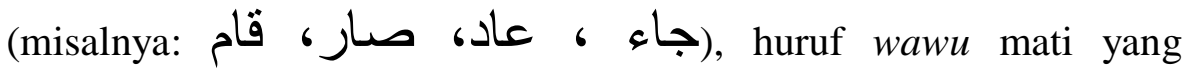
didahului oleh dhammah (misalnya: علوم، مسلمون، مؤمنون، معلمون), dan huruf ya mati yang didahului oleh kasrah (misalnya: (مسلمبن، مؤمنين، مثر كين، مساكبن.

Suatu kata bahasa Arab yang terdapat vokal panjang di dalamnya memiliki arti atau makna yang tidak sama dengan kata yang sama namun berbeda panjang atau pendeknya. Tentunya perubahan vokal dari panjang ke pendek atau sebaliknya akan memberikan pengeruh terhadap makna yang dimunculkan.

- Vokal Pendek

Kebalikan dari jenis vokal di atas yaitu vokal pendek. Dalam bahasa Arab beberapa huruf yang termasuk mengandung vokal pendek yaitu

2. Aspek Tebal Tipisnya Vokal

Pada aspek ini, pembagian bunyi vokal dalam bahasa Arab dibagi menjadi tiga macam vokal, yaitu vokal tebal, vokal semi tebal dan vokal tipis. Adapun yang termasuk fonem, yang membedakan bentuk dan arti suatu kata yaitu vokal tipis. Penjelasan ketiga macam vokal ditinjau dari tebal tipisnya vokal yaitu sebagai berikut: 
a. Vokal tebal

Vokal tebal atau disebut pula dengan mufakhamah, yaitu jika vokal ص -ض - ط : terdapat pada konsonan platal. Konsonan platal yaitu صنع - ضحك - طال - ظبط - misalnya -

b. Vokal semi tebal

Vokal semi tebal yaitu jika vokal terdapat pada konsonan velar. Kفل - خبر - قلق

c. Vokal tipis

Adapun yang termasuk pada kategori vokal tipis yaitu semua vokal yang ada dalam konsonan kecuali konsonan tersebut di atas. Misalnya ذهب - رجع - نفع

\section{Aspek Tunggal Majemuknya Vokal}

Pembagian ini didasarkan pada ada atau tidaknya gabungan dari beberapa vokal asli. Vokal tunggal disebut pula monoftong, sedangkan vokal rangkap atau majemuk disebut dengan diftong (untuk gabungan dua قيم - سبر: vokal) dan triftong (untuk gabungan tiga vokal). Misalnya

\section{bو امت، حروف}

Konsonan merupakan bunyi bahasa yang muncul dari hasil hambatan aliran udara pada salah satu tempat di saluran suara di atas glotis. ${ }^{10}$ Proses produksi pada bunyi ini terjadi aliran udara yang melewati mulut dihambat pada tempat-tempat artikulasi. Bisa bunyi letupan, geseran, bunyi bersuara dan tidak bersuara. Konsonan selalu mendapatkan hambatan di saluran udara, baik hambatan kuat atau lemah sehingga mengakibatkan adanya letupan atau

\footnotetext{
${ }^{9}$ Kamal Muhammad Bisyr,al-Aswat al- 'Arabiyah,(Kairo:Maktabah al-Syabab,1991),hlm.148,

10 Sakholid,Pengantar Linguistik; Analisis Teori-teori Linguistic dalam Bahasa Arab,(Medan:Nara
} Press,2006),hlm.73. 
geseran. Bunyi yang termasuk konsonan yaitu semua bunyi yang udaranya keluar dari hidung ketika diartikulasikan atau bunyi udara keluar dari samping kiri atau kanan mulut. Konsonan dalam bahasa Arab berjumlah 26, di antarnya yaitu: ب - ذ- - م- - - - - -

Sebagian ahli bahasa mengatakan bahwa konsonan dalam bahasa Arab terdiri dari 28 konsonan. Ada pula yang mengatakan bahwa konsonan bahasa Arab berjumlah 26 konsonan. Para ahli bahasa yang menyebutkan bahwa 26 konsonan dalam bahasa Arab, mereka tidak memasukkan semivokal wawu-ya ke dalam konsosnan sebagaimana yang dilakukan oleh para ahli bahasa yang menyebutkan 28 konsonan bahasa Arab. Perbedaan antara semivokal dengan konsonan ini adalah hanya pada tataran ilmiah, namun pada praktiknya orang cenderung menganggap keduanya adalah sama. Semivokal selain memiliki sifat-sifat konsonan, juga memiliki sifat-sifat yang dimiliki vokal. ${ }^{11}$

c. Semi Vokal atau نصف الحركات

Jenis bunyi ini dinamakan juga denga semi konsonan, karena sifat yang dimiliki banyak kesamaan dengan sifat konsonan, seperti tidak jelas terdengar dan waktunya cepat dalam menuturkannya. Bunyi semi vocal ketika akan dituturkan, organ bicara telah mengambil posisi seperti hendak menuturkan sebuah vocal tertentu, kemudian dengan cepat organ bicara tersebut mengubah posisi seperti akan menuturkan sebuah vokal lain. Singkatnya bunyi yang keluar itu bukan yang pertama dan ke dua, akan tetapi bunyi yang lain. Misalnya bunyi $-9 .^{12}$

Bunyi semivokal memiliki cara penuturan yang mirip dengan penuturan bunyi vokal. ${ }^{13}$ Pada praktinya memang hampir sama dengan konsonan. Tempat keluarnya bunyi yang menjadi titik penghambatan terhadap arus udara yang datang dari paru-paru. Berdasarkan hambatannya, ada dua macam bunyi semi vokal, yaitu:

${ }^{11}$ Ahmad Sayuti Anshari Nasution,Bunyi Bahasa;Ilm ,(Jakarta:Amzah, 2010),hlm.93-94

${ }^{12}$ Ibid,hlm.65-66

${ }^{13}$ Kamal Muhammad Bisyr,al-Aswat ,(Kairo:Maktabah al-Syabab,1991),hlm.133 
1. Semivokal bilabial, yaitu semi vokal yang terjadi ketika artikulator aktifnya bibir bawah dan artikulator pasif bibir atas. Bunyi yang dihasilkan adalah bunyi (w).

2. Semivokal medio-palatal, yaitu semi vokal yang terjadi ketika artikulator aktifnya tengah lidah dan artikulator pasifnya langit-langit keras

\section{FONEM BAHASA ARAB}

\section{Fonem Vokal Bahasa Arab}

Meskipun fonem sebagai satuan terkecil dalam bunyi bahasa, akan tetapi memiliki peran yang sangat besar dalam menentukan suatu makna bunyi bahasa dalam bahasa Arab. Tidak hanya dari aspek perbedaan huruf yang membuat makna menjadi tidak sama, namun juga dipengaruhi pula oleh panjang pendeknya bunyi bahasa. Fonem yang bunyinya pendek tidak sama maknanya denan fonem yang bunyinya panjang dalam bahasa Arab. Vokal dalam bahasa Arab mencakup bunyi fathah, kasrah dan dhammah. Berikut beberapa contoh fonem vokal dalam bahasa Arab ditinjau dari panjang pendeknya bunyi bahasa, atau dalam bahasa Arab dikenal dengan nama mad.

a. Fonem Vokal Fathah

Kata لاريب لريب la royba). Kedua kata tersebut memiliki kemiripan bunyi dan jumlah bunyinya sama (empat bunyi). Perbedaan kedua kata tersebut terletak pada aspek panjang pendeknya bunyi yang tentunya mempengaruhi terhadap makna yang berbeda. Bunyi la dan $l a>$, keduanya adalah merupakan fonem. Jika la dalam kata la royba yang berarti benar-benar ada keraguan, kemudian diganti dengan $l a>$ dalam kata la> royba maka akan menjadi tidak ada keraguan, sehingga hal ini mempengaruhi terhadap perubahan makna.

\section{b. Fonem Vokal Kashrah}

Kata مسلمين (muslimin) dengan مسلم (muslimi>n). Kedua kata tersebut memiliki kemiripan bunyi. Perbedaan kedua kata tersebut terletak pada aspek panjang pendeknya bunyi yang tentunya mempengaruhi terhadap makna yang berbeda. Bunyi $m i$ dan $m i>$, keduanya adalah merupakan fonem. Jika $m i$ dalam kata muslimin yang berarti seorang muslim, kemudian diganti dengan $m i>$ dalam kata muslimi $>n$ maka akan menjadi bentuk jamak orang-orang muslim, sehingga hal ini mempengaruhi terhadap perubahan makna. 


\section{c. Fonem Vokal Dhammah}

Kata محبون (muhibun) dengan محب (muhibu>n). Kedua kata tersebut memiliki kemiripan bunyi. Perbedaan kedua kata tersebut terletak pada aspek panjang pendeknya bunyi yang tentunya mempengaruhi terhadap makna yang berbeda. Bunyi $b u$ dan $b u>$, keduanya adalah merupakan fonem. Jika $b u$ dalam kata muhibun yang berarti seorang yang disukai, kemudian diganti dengan $b u>$ dalam kata muhibu>n maka akan menjadi bentuk jamak orangorang yang disukai, sehingga hal ini mempengaruhi terhadap perubahan makna.

Selain beberapa pembagian macam fonem vokal tersebut di atas, ada pula macam vokal yang dapat berpengaruh terhadap bentuk dan makna kata. Pembagian tersebut yaitu atas dasar tebal tipisnya vokal. Khususnya pada aspek vokal tipis. Misanya شر ح 2 dan 2 yang keduanya tedapat vokal tipis. Kata yang pertama memiliki arti berjalan, sedangkan kata yang kedua berarti menjelaskan.

\section{Fonem Konsonan Bahasa Arab}

Fonem konsonan dalam bahasa Arab dapat dijumpai pada dua kata yang memiliki kemiripan atau kesamaan dalam bahasa Arab, namun secara konsonan yang digunakan tidak sama. Tentunya makna pada masing-masing dua kata tersebut pastilah tidak sama.

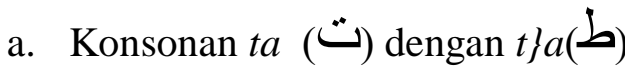

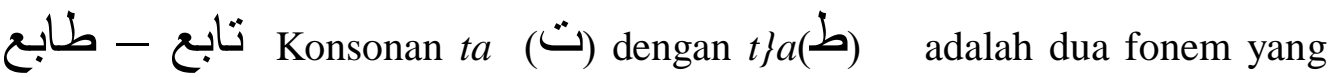
berbeda dan dapat membedakan makna. Makna kata yang terkandung yaitu pencetak dan pengikut.

b. Konsonan ta $(\stackrel{\bullet}{)})$ dengan $d a(\lrcorner)$

Konsonan ta $(\stackrel{*}{)}$ ) dengan $d a(د)$ adalah dua fonem yang berbeda dan dapat membedakan makna. Makna kata yang terkandung yaitu selesai dan darah.

c. Konsonan $k a$ (S) dengan $q a(\ddot{G})$

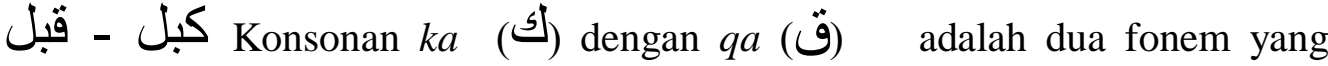
berbeda dan dapat membedakan makna. Makna kata yang terkandung yaitu menjamin dan membelenggu. 
d. Konsonan $d a(د)$ dengan $d\} a$ (ض)

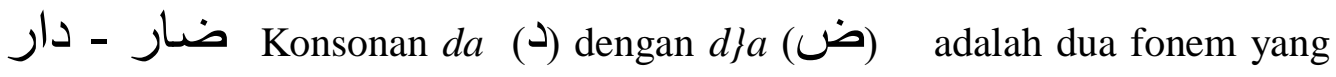
berbeda dan dapat membedakan makna. Makna kata yang terkandung yaitu rumah dan ganas.

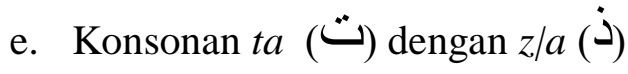

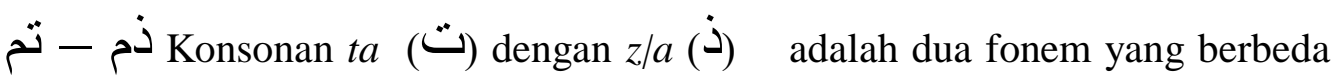
dan dapat membedakan makna. Makna kata yang terkandung yaitu sempurna dan mempersalahkan.

f. Konsonan $z \mid a$ (ذ) dengan $z\{a(\dot{\text { (ذ) }})$

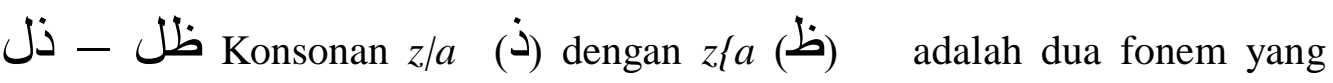
berbeda dan dapat membedakan makna. Makna kata yang terkandung yaitu rendah dan melanjutkan.

g. Konsonan sa (س) dengan $s\} a(ص)$

Konsonan sa (سبح ) سبح) dengan s\}alah dua fonem yang berbeda dan dapat membedakan makna. Makna kata yang terkandung yaitu memuji dan mengucapkan selamat pagi.

h. Konsonan sa (س) dengan sya (ش)

Konsonan sa (سبح - شبح) dengan sya (ش) شبح ) adalah dua fonem yang berbeda dan dapat membedakan makna. Makna kata yang terkandung yaitu berenang dan membentangkan.

i. Konsonan $h f a$ (乙) dengan $h a(\bullet)$

Konsonan $h\} a$ (ح) dengan $h a(0)$ adalah dua fonem yang berbeda dan dapat membedakan makna. Makna kata yang terkandung yaitu keadaan dan menakut-nakuti.

j. Konsonan $h\} a(\mathcal{C})$ dengan ' ( $)$

Konsonan $h\} a$ (ح) dengan (ع) adalah dua fonem yang berbeda dan dapat membedakan makna. Makna kata yang terkandung yaitu mencondongkan dan mengetahui. 
k. Konsonan kha $(\dot{\mathcal{乙}})$ dengan $\mathrm{g}(\dot{\boldsymbol{\varepsilon}})$

Konsonan kha (خ) dengan g (غ) (亡) ) - غلق berbeda dan dapat membedakan makna. Makna kata yang terkandung yaitu menutup dan menciptakan.

1. Konsonan $z a(j)$ dengan $j a(ج)$

جر - Konsonan za (j) dengan jaج) adalah dua fonem yang berbeda dan dapat membedakan makna. Makna kata yang terkandung yaitu mengeraskan dan bersinar.

\section{E. PENUTUP}

Fonologi merupakan salah satu bidang atau cabang dalam kajian ilmu linguistik yang membahas tentang bunyi-bunyi bahasa. Bunyi bahasa ini dikategorikan menjadi dua, salah satunya yang menjadi pembahasan dalam tulisan ini yaitu fonemik. Fonem membahas tentang bunyi bahasa yang berpengaruh terhadap makna. Berdasarkan pembagian bunyi atas karakteristiknya, para linguis membagi bunyi menjadi tiga macam, yaitu: vokal atau صوائت، حركات (Aspek Panjang Pendeknya Vokal; vokal panjang dan vokal pendek, Aspek Tebal Tipisnya Vokal; vokal tebal, vokal semi tebal dan vokal tipis, Aspek Tunggal Majemuknya Vokal), konsonan رو امث6 dan semi vokal نصف الحركات. Fonem vokal sendiri dalam bahasa Arab terdiri dari fonem vokal fathah, fonem vokal kashrah, dan fonem vokal dhammah. Kesemua fonem tersebut dalam bahasa Arab memiliki pengaruh terhadap pembentukan makna yang terkandung pada setiap kata. Kata dengan fonem di dalamnya yang berbeda tentunya makna yang dihasilkan pun juga tidak sama.

\section{F. DAFTAR PUSTAKA}

Ali Al-Khouli,Muhammad.1982.Mu'jam Ilmu Al-Aswat.Riyadh:Universitas Riyadh.Cet I

Bisyr, Kamal Muhamed.1991.al-Aswat al'Arabiyyah.Kairo: Maktabah al-Syabab Chaer,Abdul.2007.Linguistik Umum.Jakarta:Rineka Cipta

Kridalaksana,Harimurti.1983.Kamus Linguistik.Jakarta: Gramedia 
Muslich,Masnur.2014.Fonologi Bahasa Indonesia; Tinjauan Dekriptif Sistem Bunyi Bahasa Indonesia.Jakarta: Bumi Aksara

Rasyidi, Abdul Wahab.2010. 'Ilmu al-Aswat al-Nitqi.Malang: UIN Maliki Press

Sakholid.2006.Pengantar Linguistik; Analisis Teori-teori Linguistic dalam Bahasa Arab. Medan:Nara Press

Sayuti Anshari Nasution,Ahmad.2010.Bunyi Bahasa;Ilm Al-Ashwat Al 'Arabiyyah. Jakarta:Amzah

Sudaryat, Yayat.2009.Makna dalam Wacana.Bandung: CV Yrama Widya 